\title{
PENINGKATAN KEMAMPUAN MENYIMAK ANAK USIA 5-6 TAHUN MELALUI METODE WHOLE BRAIN TEACHING
}

\author{
Defista Nur Hafrianti ${ }^{1}$, Siti Wahyuningsih ${ }^{1}$, Vera Sholeha ${ }^{1}$ \\ ${ }^{1}$ Pendidikan Guru Pendidikan Anak Usia Dini, Universitas Sebelas Maret Surakarta \\ defista02@student.uns.ac.id, siti_w@staff.uns.ac.id, verasholeha@staff.uns.ac.id
}

\begin{abstract}
ABSTRAK
Penelitian ini bertujuan untuk mengetahui peningkatan kemampuan menyimak anak usia 5-6 tahun di TK Pertiwi Lebak Wonogiri tahun ajaran 2019/2020 melalui penerapan metode whole brain teaching. Penelitian dilakukan dengan pendekatan kualitatif dan kuantitatif melalui penelitian tindakan kelas, menggunakan model Kemmis dan Taggart. Subjek penelitian adalah anak usia 5-6 tahun, sejumlah 34 anak yang terdiri dari 17 anak perempuan dan 17 anak laki-laki. Sumber data dalam penelitian yaitu anak usia 5-6 tahun, guru, serta hasil penilaian kemampuan menyimak yang merupakan sumber data primer. Sumber data sekunder berupa RPPH, foto, video, dan lembar penilaian anak. Teknik pengumpulan data kuantitatif: tes, teknik pengumpulan data kualitatif: wawancara, observasi, serta dokumentasi. Teknik uji validitas data kuantitatif dengan validitas konstruk, sedangkan uji validitas kualitatif menggunakan triangulasi teknik dan triangulasi sumber. Teknik analisis data kuantitatif menggunakan deskriptif komparatif, teknik analisis data kualitatif dengan analisis model interaktif Miles dan Huberman. Hasil penelitian ini menunjukkan peningkatan pada setiap siklus. Persentase ketuntasan kemampuan menyimak pada siklus I diperoleh 55,9\%, pada siklus II naik menjadi 82,3\%. Peningkatan ini terjadi pada indikator menceritakan kembali informasi yang di dengar dengan urutan yang benar, melaksanakan aturan dalam kegiatan, dan memusatkan perhatian dalam mengikuti kegiatan. Berdasar pada hasil penelitian, dapat di tarik kesimpulan bahwa kemampuan menyimak anak usia 5-6 tahun di TK Pertiwi Lebak Wonogiri tahun ajaran 2019/2020 dapat ditingkatkan melalui penerapan metode whole brain teaching.
\end{abstract}

Kata kunci : kemampuan menyimak, anak usia 5-6 tahun, metode whole brain teaching

\begin{abstract}
This study aims to determine the increase in listening skill of children aged 5-6 years at TK Pertiwi Lebak Wonogiri in the academic year of 2019/2020 through the application of the whole brain teaching method. This study was conducted with a qualitative and quantitative approach through classroom action research, using Kemmis and Taggart's models. The subjects of this study were children aged 5-6 years old, a number of 34 children consisting of 17 girls and 17 boys. Sources of data in the study were children aged 5-6 years old, teacher, and the results of the listening skill assessment which were the primary data sources. Secondary data sources are RPPH, photos, videos, and child assessment sheets. Quantitative data collection techniques: test, and qualitative data collection techniques: interviews, observation, and documentation. The technique of testing the validity of quantitative data with construct validity, while the qualitative validity test used technical triangulation and source triangulation. The quantitative data analysis technique uses comparative descriptive, while the qualitative data analysis technique uses the interactive model analysis by Miles and Huberman. The results of this study indicate an increase in each cycle. The percentage of completeness of the listening skill in the first cycle was obtained 55,9\% then in the second cycle it increased to $82,3 \%$. This increase occurs in indicators of retelling information with appropriate order, applying rules in performing activities, and keeping the focus on certain activities. Based on the results of the study, it can be concluded that the listening skill of children aged 5-6 year at TK Pertiwi Lebak Wonogiri in the academic year of 2019/2020 can be improved through the application of the whole brain teaching method.
\end{abstract}

Keywords : Listening skill, children aged 5-6 years old, whole brain teaching method 


\section{PENDAHULUAN}

\section{Masa usia dini adalah masa dimana seseorang mengalami pertumbuhan dan perkembangan yang sangat pesat dalam kehidupannya.} Pertumbuhan dan perkembangan pada anak usia dini membutuhkan bermacammacam stimulasi untuk membantunya berkembang dengan baik sesuai dengan potensi yang dimiliki dan kebutuhannya. Salah satu aspek perkembangan yang perlu distimulasi yaitu perkembangan bahasa. Menurut Vygotsky (Upton, 2012) bahasa merupakan salah satu alat budaya dan berperan penting sebagai perantara terjadinya proses belajar. Dengan adanya proses interaksi yang baik, maka anak akan dapat menerima informasi atau materi dengan baik, sehingga proses belajar berjalan dengan optimal.

Bourdeaud, Aesaert, Keer, \& Braak (2018) mengungkapkan bahwa kemampuan menyimak merupakan kemampuan pertama dari perkembangan bahasa. Menyimak bagi anak merupakan dasar untuk belajar bahasa maupun yang lainnya, karena melalui menyimak anak akan memperoleh suatu informasi. Badiah (2017) menjelaskan bahwa menyimak adalah proses kegiatan mendengar lambang-lambang lisan penuh perhatian, apresiasi, pemahaman, interpretasi untuk mendapatkan informasi, menangkap pesan atau informasi serta memahami arti komunikasi yang telah disampaikan oleh pembicara melalui ujaran atau bahasa lain. Proses belajar menyimak secara terus menerus dilakukan dengan cara mendengar atau merekam kata-kata yang didengarnya di kehidupan sehari-hari. Kemampuan menyimak termasuk dalam ranah perkembangan memahami bahasa atau bahasa reseptif, tingkat pencapaian perkembangan anak usia 5-6 tahun dalam hal memahami bahasa yaitu: 1) mengerti beberapa perintah secara bersamaan, 2) mengulang kalimat yang lebih kompleks, 3) memahami aturan dalam suatu permainan, 4) senang dan menghargai bacaan (Kemdikbud, 2014a). Kemudian, indikator kemampuan menyimak anak usia 5-6 tahun yang di adaptasi dari pendapat Kemdikbud (2014) pada Permendikbud No. 146 Tahun 2014, Tarigan (2008), dan Jalongo (Hartati \& Novrika, 2018) yaitu: 1) menceritakan kembali informasi yang di dengar dengan urutan yang benar, 2) melaksanakan aturan dalam kegiatan, 3) memusatkan perhatian dalam mengikuti kegiatan.

$$
\begin{aligned}
& \text { Berdasarkan observasi yang } \\
& \text { dilakukan di TK Pertiwi Lebak, } \\
& \text { kemampuan menyimak anak masih kurang } \\
& \text { berkembang dengan baik. Terutama pada } \\
& \text { saat menceritakan kembali informasi yang }
\end{aligned}
$$


di dengar dengan urutan yang benar, anakanak masih mengikuti ucapan guru di awal kalimat atau akhir kalimat saja, masih banyak anak yang tidak menirukan dan tidak memperhatikan. Pada saat kegiatan upacara hari Senin, guru memberikan 5 aturan yang berupa instruksi atau aba-aba kepada anak. Tetapi sebagian besar anak hanya dapat melaksanakan 1-2 aturan dalam kegiatan tersebut. Dalam hal memusatkan perhatian, lebih dari 50\% anak di kelas masih mengalihkan perhatiannya pada aktivitas lain seperti: mengajak teman disebelahnya mengobrol sendiri, mengalihkan pandangan ke luar kelas dalam mengikuti kegiatan belajar.

Salah satu cara yang dapat dilakukan untuk mengembangkan kemampuan menyimak anak yaitu dengan menerapkan metode whole brain teaching . Whole brain melibatkan kognitif, motorik, visual, perhatian, persepsi, serta pemrosesan emosional (Kepinska, Rover, Caspers, \& Schiller, 2016). Pembelajaran di kemas sebagai bentuk permainan yang diharapkan dapat membuat anak di Taman Kanak-kanak merasa senang, tertantang, terinspirasi, dan nyaman dalam berinteraksi. Berdasarkan penelitian sebelumnya yang dilakukan oleh Atmadja pada tahun (2016), metode whole brain teaching menekankan anak untuk aktif terlibat pada proses pembelajaran sehingga dapat membantu anak untuk menyimak. Kelebihan dari metode whole brain teaching yaitu membuat anak-anak patuh terhadap aturan, memberi kesempatan anak untuk aktif bertanya, memperoleh kemampuan berbahasa yang benar dan baik, serta dapat meningkatkan kemampuan daya ingat anak (Puspitasari, 2019). Selain itu, dengan adanya aktivitas gerakan dalam langkah-langkah pelaksanaan metode whole brain teaching dapat membantu anak berkonsentrasi. Hal ini dikarenakan gerakan-gerakan dapat memberikan rangsangan pada otak kiri dan kanan sehingga dapat meningkatkan konsentrasi. Selaras dengan pendapat Nunung (Yanti, Bahri, \& Fajriani, 2018) yang menyatakan bahwa gerakan sederhana dapat merangsang integritas kerja otak kiri dan kanan untuk menghasilkan koordinasi fungsi otak yang harmonis, sehingga meningkatkan konsentrasi, kemampuan koordinasi tubuh, memori, pemecahan masalah, serta kreativitas. Dengan demikian, metode whole brain teaching merupakan upaya untuk menarik perhatian anak supaya lebih fokus atau berpusat kepada materi yang diberikan guru, serta menekankan anak aktif terlibat dalam proses pembelajaran. Keterlibatan anak pada pelaksanaan penerapan metode ini yaitu anak diminta untuk menirukan ucapan dan gerakan 
guru. Anak diberikan kesempatan untuk menyampaikan cerita yang telah disimak kepada temannya secara bergantian. Hal tersebut membentuk anak untuk mengingat dan menyimak. Jadi, anak tidak hanya pasif dalam proses ini. Sehingga dapat membantu meningkatkan kemampuan menyimak.

Berdasarkan uraian di atas, maka peneliti tertarik untuk melaksanakan penelitian mengenai peningkatan kemampuan menyimak pada anak usia 5-6 tahun dengan metode whole brain teaching. Tujuan penelitian ini "untuk meningkatkan kemampuan menyimak anak usia 5-6 tahun dengan metode whole brain teaching di TK Pertiwi Lebak Wonogiri pada tahun ajaran 2019/2020”.

\section{Kemampuan Menyimak Anak Usia 5-6} Tahun

Kemampuan menyimak sangat diperlukan dalam berkehidupan, baik dalam proses belajar maupun kegiatan yang lainnya. Menurut Badiah (2017) menyimak adalah proses kegiatan mendengar lambang-lambang lisan dengan penuh perhatian, apresiasi, pemahaman, interpretasi untuk mendapatkan informasi, menangkap pesan atau informasi dan memahami arti komunikasi yang telah disampaikan oleh penyampai informasi melalui ujaran atau bahasa lain. Jalongo (Hartati \& Novrika, 2018) berpendapat, "listening is the process of taking in information through the sense of hearing and making meaning from what was heard". Berdasarkan pendapat tersebut, menyimak merupakan proses menerima informasi melalui indera pendengaran dan memahami makna dari apa yang telah di dengar. Sedangkan Dhieni (2008) mengungkapkan bahwa kemampuan menyimak melibatkan proses menerjemahkan suara yang di dengar dan proses menginterpretasikan sehingga mempunyai makna tertentu. Kemampuan tersebut memuat proses kognitif yang membutuhkan konsentrasi dan perhatian dalam memahami pesan atau informasi yang disampaikan. Kegiatan menyimak didalamnya terdapat faktor perhatian, kesengajaan, serta usaha untuk memahami hal yang disimak.

Tarigan (2008) menyebutkan kemampuan menyimak anak taman kanakkanak usia 4,5 hingga 6 tahun, diantaranya: 1) menyimak pada temanteman sebaya dalam kelompok-kelompok bermain, 2) mengembangkan waktu perhatian yang amat panjang terhadap cerita atau dongeng, 3) dapat mengingat petunjuk-petunjuk dan pesan-pesan yang sederhana. Menurut Berg (Priyanto, 2014) anak usia 5 tahun memiliki waktu yang wajar untuk duduk dan memperhatikan dengan nyaman yaitu selama 10 menit. 
Tidak kalah pentingnya, Jalongo (Hartati \& Novrika, 2018) mengungkapkan karakteristik kemampuan menyimak anak usia 5 hingga 6 tahun, sebagai berikut:

Listens longer stories and identifies with story characters; understands and uses all types sentences and clauses (e.g., "Yes, you can go outside but first you need to put on your boots."); retains information in the correct sequence (e.g., "can retell a familiar story in considerable detail).

Kemampuan menyimak adalah kemampuan dasar yang seharusnya dimiliki oleh anak. Kemampuan ini sangat berperan dalam kehidupan sehari-hari. Jalongo (Hartati \& Novrika, 2018) berpendapat, "listening comprehension prepares young children for later reading comprehension". Kemampuan membaca pada anak dapat dipersiapkan dengan mengoptimalkan kemampuan menyimak anak. Sementara itu, Sabarti (Dhieni \& Dkk, 2008) menyebutkan beberapa manfaat dari kemampuan menyimak, antara lain: 1) menjadi dasar dalam belajar bahasa, 2) penunjang keterampilan membaca, berbicara, dan menulis, 3) penunjang dalam komunikasi lisan, 4) menambah pengetahuan atau informasi. Meskipun secara alamiah setiap anak normal menguasai kemampuan menyimak, namun kemampuan ini perlu dikembangkan dan diberikan latihan- latihan guna mengoptimalkan kemampuan berbahasa anak. Tarigan (2008) juga mengungkapkan manfaat dari menyimak, yaitu dapat menjadikan hubungan antar individu lebih efektif, dapat mengumpulkan informasi untuk membuat suatu keputusan yang sesuai dengan logika, dapat memperoleh suatu informasi, serta dapat memberikan tanggapan yang positif. Sedangkan Gulec dan Durmus (2015) menyatakan manfaat serta alasan pentingnya kemampuan menyimak pada anak yaitu sebagai media untuk memperoleh dan memproses informasi yang erat kaitannya dengan pengetahuan anak, sebagai kunci keberhasilan dalam pengembangan pemahaman membaca dan keterampilan menulis, untuk memahami instruksi dari guru, serta berperan dalam pengembangan hubungan sosial.

\section{Metode Whole Brain Teaching}

Whole brain teaching merupakan metode dalam proses pembelajaran yang dikembangkan oleh Chris Biffle pada tahun 1999 di Amerika. Metode ini terdiri dari tujuh tenik atau langkah dalam penerapannya yang dikenal dengan "The Big Seven". Heeter dan Efird (Preslee \& Prakasha, 2017) menyatakan bahwa tujuh langkah tersebut dapat disusun ulang, dicampur, disesuaikan dengan masingmasing guru. Mukrimah (2014) menjelaskan bahwa metode whole brain 
teaching adalah metode pembelajaran yang penerapannya menggunakan perintah-perintah dan respon-respon sederhana. Pembelajaran dilakukan dengan mengenali prinsip belajar visual, verbal, dan kinestetik. Chris Biffle (Aulina, 2018) juga menyatakan bahwa whole brain teaching merupakan pembelajaran dengan didasarkan pada fungsi otak kanan dan kiri. Inti metode whole brain teaching yaitu salah satu metode yang digunakan sebagai upaya untuk menarik perhatian anak didik agar lebih fokus pada materi yang diberikan guru. Pembelajaran ini merupakan gambaran neurolingusitik dengan menggunakan pendekatan instruksional. Neurolinguistik sendiri merupakan bidang ilmu yang mempelajari bagaimana kerja otak dalam memproses kegiatan mendengar, membaca, berbicara, dan menulis menjadi suatu informasi.

Istilah-istilah dalam metode whole brain teaching menurut Chris Biffle (Preslee \& Prakasha, 2017) adalah: 1) Class-yes, pada tahap ini guru menarik perhatian anak. Guru memulai kelas dengan mengucapkan "class" sesuai dengan intonasi yang diingkan, kemudian anak meniru intonasi dengan menjawab "yes". Terjadi pengaktifan korteks prefrontal, belajar akan efektif jika bagian otak ini aktif. 2) Classroom Rules : The organizer, guru menggunakan lima aturan kelas. Setiap aturan terkait dengan gerakannya masing-masing. Gerakan tersebut mengaktifkan korteks motorik anak yang berfungsi sebagai penyimpan memori dan gerakan ini membuat aturan belajar menjadi menyenangkan untuk dipraktikkan. 3) Hands and eyes : The focusor. Ketika guru berkata "hands and eyes" anak-anak akan menjawab seperti yang diucapkan oleh guru. Teknik ini membantu guru untuk mendapatkan perhatian maksimal dari anak. Teknik ini dapat digunakan oleh guru ketika ingin mendapatkan perhatian yang lebih dari anak. 4) Teach-okay: Whole brain activator. Memberikan kesempatan pada anak untuk saling mengajar. Cannon (Preslee \& Prakasha, 2017) berpendapat bahwa dalam langkah teach-ok memberikan kesempatan anak untuk mendapatkan kepercayaan diri dan meningkatkan keterlibatan anak. Ketika anak saling mengajar, guru memastikan semua anak ikut berpartisipasi dan memberikan umpan balik secara langsung. Pada tahap ini lima area otak terstimulasi. Korteks visual ketika anak melihat dan mengikuti gerakan guru, korteks motorik ketika anak bergerak, area broca ketika anak saling mengajar, area wernicke ketika anak mendengarkan apa yang disampaikan guru, dan sistem limbic ketika anak menunjukkan emosi pada saat kegiatan ini. 
5) Mirror: The Class Unifer. Guru mengucapkan "mirror" dan anak menjawab "mirror". Kemudian anak meniru kata-kata dan gerakan guru. 6) Switch: The involver. Satu anak sebagai pendengar dan satu anak sebagai penyampai informasi. Pada tahap ini, ketika guru berkata "switch" maka anak bertukar posisi. Teknik ini meningkatkan keterampilan mendengarkan pembicara dan keterampilan berbicara kepada pendengar. 7) The score board: The motivator. Untuk mendukung perhatian dan motivasi anak di kelas, guru menyiapkan papan skor. Tujuan papan skor bukan untuk mengubah perilaku anak, tetapi untuk memotivasi anak.

Nursulistyo (2014) juga menyatakan kelebihan dari metode ini adalah anak fokus dan perhatiannya selalu tertuju pada guru, sehingga penyampaian informasi atau materi menjadi lebih optimal. Selain itu, anak mendapatkan penguatan materi dari tahapan pengulangan konsep dan ketika saling mengajar dengan temannya. Sementara itu, menurut Novidayanti (2018) kelebihan dari metode whole brain teaching adalah menumbuhkan konsentrasi serta partisipasi anak dalam kegiatan pembelajaran, mengesankan sehingga materi mudah diingat oleh anak, meningkatkan tingkat keaktifan anak dalam mengikuti kegiatan pembelajaran, dan tidak hanya berpusat pada guru sehingga dapat meningkatkan motivasi dan kemampuan berkomunikasi. Metode ini juga mempunyai kekurangan, yaitu sangat menuntut kesadaran anak untuk ikut berpartisipasi, dan potensi kelas menjadi tidak kondusif juga meningkat.

\section{METODE}

Penelitian dilaksanakan di TK Pertiwi Lebak, Kecamatan Pracimantoro, Kabupaten Wonogiri. Waktu yang dibutuhkan untuk melakukan penelitian yaitu selama 8 bulan, di mulai pada akhir bulan November 2019 hingga awal bulan Juli 2020. Penelitian ini dengan pendekatan kuantitatif dan kualitatif menggunakan penelitian tindakan kelas. Model penelitian yang digunakan adalah model Kemmis \& McTaggart dengan dua siklus. Subjek dalam penelitian ini yaitu anak usia 5-6 tahun sejumlah 34 anak, yang terdiri dari 17 anak perempuan dan 17 anak laki-laki.

Sumber data penelitian, sumber data primer yaitu anak usia 5-6 tahun, guru, serta hasil penilaian kemampuan menyimak. Sumber data sekunder berupa $\mathrm{RPPH}$, foto, video, dan lembar penilaian anak. Teknik pengumpulan data kuantitatif dilakukan dengan tes, teknik pengumpulan data kualitatif dilakukan melalui wawancara, observasi, dan dokumentasi. 
Uji validitas data kualitatif menggunakan triangulasi taknik dan triangulasi sumber, sedangkan uji validitas data kuantitatif dengan validitas konstruk. Analisis data kuantitatif menggunakan teknik analisis data komparatif, teknik analisis data kualitatif dengan analisis model interaktif Miles dan Huberman (Sugiyono, 2015) berupa pengumpulan data, reduksi data, penyajian data, dan penarikan kesimpulan.

\section{HASIL DAN PEMBAHASAN}

Penelitian dilakukan dengan dua siklus yang mana tiap siklusnya terdiri dari tiga pertemuan. Setiap pertemuan dilakukan dengan adanya perencanaan, pelaksanaan tindakan dan observasi, serta refleksi. Adapun data hasil ketuntasan kemampuan menyimak anak usia 5-6 tahun TK Pertiwi Lebak Wonogiri tahun ajaran 2019/2020 siklus I dan siklus II terdapat pada tabel 1 berikut:

Tabel 1. Hasil Ketuntasan Kemampuan Menyimak Tiap Indikator

\begin{tabular}{lccc}
\hline \multicolumn{1}{c}{ Indikator } & $\begin{array}{c}\text { Pra } \\
\text { tindakan }\end{array}$ & $\begin{array}{c}\text { Siklus } \\
\text { I }\end{array}$ & $\begin{array}{c}\text { Siklus } \\
\text { II }\end{array}$ \\
\hline $\begin{array}{l}\text { Menceritakan } \\
\text { kembali } \\
\text { informasi yang di } \\
\text { dengar dengan }\end{array}$ & $38,2 \%$ & $61,8 \%$ & $82,3 \%$ \\
$\begin{array}{l}\text { urutan yang benar } \\
\text { Melaksanakan } \\
\text { aturan dalam } \\
\text { kegiatan } \\
\begin{array}{l}\text { Memusatkan } \\
\text { perhatian dalam } \\
\text { mengikuti } \\
\text { kegiatan }\end{array}\end{array}$ & & & \\
\hline
\end{tabular}

Tabel 1 di atas menunjukkan perbandingan hasil ketuntasan yang diperoleh pada tiap siklus. Peningkatan yang terjadi ditandai dengan meningkatnya persentase ketuntasan pada masing-masing indikator di setiap siklusnya. Kemampuan menyimak anak pada indikator menceritakan kembali informasi yang di dengar dengan urutan yang benar, pada pratindakan ketuntasan sebesar 38,2\%. 13 anak dari 34 anak dapat menceritakan kembali informasi yang di dengar sesuai dengan urutan yang benar. Sebagian besar anak lainnya dapat menceritakan kembali informasi yang di dengar, tetapi belum sesuai dengan urutan yang benar. Sementara itu, terdapat 2 anak yang sama sekali belum dapat menceritakan kembali informasi yang di dengar dengan urutan yang benar.

Indikator menceritakan kembali informasi yang di dengar dengan urutan yang benar, pada siklus I mengalami peningkatan dari pratindakan. Pada siklus ini ketuntasan sebesar 61,8\%. 21 anak dapat menceritakan kembali informasi yang di dengar sesuai dengan urutan yang benar. Sedangkan 13 anak lainnya dapat menceritakan kembali informasi yang di dengar, tetapi belum sesuai dengan urutan yang benar. Pada siklus II, ketuntasan indikator ini mecapai 82,3\%. 28 anak dapat menceritakan kembali informasi 
yang di dengar sesuai dengan urutan yang benar. Enam anak lainnya dapat menceritakan kembali informasi yang di dengar, tetapi belum sesuai dengan urutan yang benar. Hal ini sesuai dengan pendapat Kemdikbud (2014) pada Permendikbud No. 146 Tahun 2014, Tarigan (2008), dan Jalongo (Hartati \& Novrika, 2018) bahwa anak usia 5-6 tahun dapat menceritakan kembali informasi yang di dengar dengan urutan yang benar. Meskipun terdapat 6 anak yang belum mencapai skor ketuntasan pada indikator ini, tetapi lebih dari $75 \%$ telah mencapai target ketuntasan.

Hasil ketuntasan pratindakan pada indikator melaksanakan aturan dalam kegiatan sebesar 41,1\%. 14 anak dapat melaksanakan 3-4 aturan dalam kegiatan. Sedangkan 18 anak lainnya dapat melaksanakan 1-2 aturan saja. Selain itu, 2 anak lainnya belum dapat melaksanakan aturan dalam kegiatan. Kemudian pada siklus I persentase ketuntasan mengalami peningkatan menjadi 61,8\%. 21 anak mencapai skor ketuntasan, yaitu dapat melaksanakan 3-4 aturan dalam kegiatan. Dan 13 anak lainnya dapat melaksanakan 1-2 aturan saja dalam mengikuti kegiatan penerapan metode whole brain teaching. Pada siklus II, persentase ketuntasan telah melampaui indikator keberhasilan belajar secara klasikal yaitu sebesar 82,3\%. 25 anak dapat melaksanakan 3-4 aturan dalam kegiatan, 3 anak dapat melaksanakan 5 aturan dalam kegiatan, dan 6 anak lainnya dapat melaksanakan 1-2 aturan dalam kegiatan.

Indikator memusatkan perhatian dalam mengikuti kegiatan pada pratindakan menunjukkan hasil ketuntasan sebesar 38,2\%. 13 anak dapat memusatkan perhatian dalam mengikuti kegiatan selama 5-7 menit. Sedangkan 16 anak lainnya dapat memusatkan perhatian selama 2-4 menit. Selain itu, ada 5 anak yang baru dapat memusatkan perhatian dalam kegiatan selama 0-1 menit. Pada siklus I, persentase ketuntasan naik menjadi 55,9\%. 19 anak yang tuntas, dapat memusatkan perhatian dalam mengikuti kegiatan selama 5-7 menit. 13 anak lainnya dapat memusatkan perhatian dalam kegiatan selama 2-4 menit. Serta 2 anak lainnya dapat memusatkan perhatian dalam kegiatan selama 0-1 menit saja. Persentase ketuntasan siklus II juga mengalami peningkatan, yaitu menjadi 82,3\%. 27 anak dapat memusatkan perhatiannya selama 5-7 menit. 5 anak dapat memusatkan perhatian selama 2-4 menit. Masih ada 1 anak yang dapat memusatkan perhatiannya selama 0-1 menit saja, tetapi terdapat 1 anak yang dapat memusatkan perhatian dalam mengikuti kegiatan selama 8-10 menit. 
Menurut Berg (Priyanto, 2014) anak usia 5 tahun memiliki waktu yang wajar untuk duduk dan memperhatikan dengan nyaman yaitu selama 10 menit. Hal ini menandakan adanya peningkatan yang baik pada indikator tersebut.

Keberhasilan kemampuan menyimak secara klasikal dalam pratindakan mencapai $38,2 \%$, siklus I sebesar 55,9\%, di siklus II mengalami peningkatan menjadi $82,3 \%$. Metode whole brain teaching efektif dan dapat digunakan dalam meningkatkan kemampuan menyimak anak. Hal ini dapat dilihat dari indikator kinerja penelitian. 28 anak di kelas telah mencapai skor ketuntasan, diantaranya: dapat menceritakan kembali informasi yang di dengar dengan urutan yang benar, dapat melaksanakan 3-4 aturan bahkan 5 aturan dalam mengikuti kegiatan, dapat memusatkan perhatian dalam mengikuti kegiatan selama 5-7 menit atau lebih, tanpa aktivitas yang lain, yang tidak ada kaitannya dengan kegiatan dan dapat menjawab pertanyaan dengan benar.

Berdasarkan hasil akhir penelitian, selain 28 anak yang mengalami peningkatan pada kemampuan menyimaknya, terdapat 6 anak yang terdiri dari 2 anak perempuan dan 4 anak laki-laki yang belum mencapai skor ketuntasan. Keenam anak tersebut tidak tuntas pada ketiga indikator karena dipengaruhi oleh beberapa faktor. Berikut faktor-faktor yang mempengaruhi belum tuntasnya keenam anak pada ketiga indikator penelitian : 1) faktor motivasi, belum memiliki motivasi yang tinggi untuk menyimak sehingga mengalami kesulitan dalam memahami informasi maupun dalam memusatkan perhatian pada saat mengikuti kegiatan. 2) faktor lingkungan keluarga. Kurangnya perhatian orangtua ketika di rumah. Beberapa anak ini telah memiliki adik diusianya yang masih membutuhkan perhatian lebih dari orangtua, sehingga orangtua dari anak tersebut tidak fokus pada perkembangannya. 3) faktor lingkungan sekolah. Letak TK yang berdekatan dengan sekolah dasar. Terkadang ada siswa sekolah dasar yang datang ke TK dan membuat perhatian anak-anak terpecah sehingga kurang kondusif bagi anak dalam kegiatan menyimak. 4) faktor lain yang juga mempengaruhi ketidaktuntasan keenam anak tersebut yaitu penggunaan media berupa gambar ternyata belum berpengaruh bagi mereka. Saran untuk kedepannya diharapkan guru dapat memberikan media yang lebih menarik, misalnya media audio visual. Hal ini seperti yang dikemukakan oleh Daeng, Amir, dan Hamsa (2010) bahwa faktorfaktor yang dapat mempengaruhi 
kemampuan menyimak antara lain adalah faktor motivasi dan faktor lingkungan.

Kegiatan penerapan metode whole brain teaching dilakukan di TK Pertiwi Lebak Wonogiri tahun ajaran 2019/2020 dengan perintah-perintah sederhana yang melibatkan pendengaran, penglihatan, berbicara, aktivitas, dan perasaaan anak, data di bawah ini di ambil dari siklus II pertemuan III adalah sebagai berikut:

1. Guru berkata "class", kemudian anakanak menjawab "yes". Seruan ini untuk menarik perhatian anak.

2. Guru bercerita singkat tentang "ani pergi ke taman' dengan menunjukkan gambar yang berhubungan dengan cerita tersebut. Kemudian guru memberikan contoh gerakan sederhana pada kalimat cerita. Kalimat yang akan disertai dengan gerakan yaitu : "Ani pergi ke taman, melihat burung terbang. Pohon-pohon bergoyang tertiup angin".

3. Guru memberikan perintah "tirukan", anak menjawab “oke”. Anak diminta untuk menirukan gerakan dan perkataan guru. Guru berkata "Ani pergi ke taman, melihat burung terbang. Pohon-pohon bergoyang tertiup angin" dengan menggunakan gerakan: seperti berjalan di tempat, tangan kanan di depan mata, mengepakkan tangan ke samping kiri dan kanan, menggoyangkan badan ke kiri dan ke kanan.

4. Guru membagi anak untuk saling berpasangan, dan membagi anak menjadi dua kelompok (nomor 1 sebagai pembicara, nomor 2 sebagai penyimak). Selanjutnya guru berkata “ajarkan”, dan anak menjawab "oke”. Kemudian yang bertugas sebagai pembicara menyampaikan cerita yang telah disampaikan oleh guru. Anak lain bertugas menyimak teman yang sedang menyampaikan cerita yang sebelumnya disampaikan oleh guru.

5. Guru berkata "bergantian”, anak menjawab "oke". Kemudian anakanak berganti tugas, yang awalnya berperan sebagai penyimak berganti sebagai pembicara dengan menyampaikan apa yang telah disampaikan oleh guru kepada temannya.

6. Selanjutnya memotivasi anak untuk melakukan tugas dengan baik di dalam kelas dengan papan skor. Anak mendapat sticker wajah tersenyum ketika dapat melakukan tugas dengan baik, jika sebaliknya maka mendapat sticker wajah menangis. Jika mendapat sticker tersenyum, anak diminta untuk berkata "yeay" sambil bertepuk tangan. Jika sebaliknya maka 
anak diminta untuk berkata "yaah" sambil melakukan gerakan seolah menangis. Arti tugas di sini yaitu dapat menyampaikan informasi kepada teman berdasarkan apa yang telah disampaikan oleh guru. Sticker yang telah di dapat, dapat ditempelkan pada papan skor modifikasi pada saat jam istirahat.

7. Memeriksa pemahaman anak atas cerita yang telah disampaikan dengan mengamati atau berkeliling kelas ketika anak menyampaikan kepada temannya. Kemudian juga dilakukan dengan melemparkan pertanyaan yang berkaitan dengan cerita tersebut.

Langkah-langkah kegiatan penerapan metode whole brain teaching dalam penelitian ini, yaitu: 1) class-yes, 2) gestures, 3) mirror, 4) teach-ok, 5) switchok, 6) scoreboard, 7) comprehession check. Langkah-langkah tersebut diadaptasi dari Chris Biffle (Aulina, 2018) akan tetapi telah disusun ulang. Hal ini didukung oleh pendapat Heeter dan Efird (Preslee \& Prakasha, 2017) yang menyatakan bahwa tujuh langkah metode whole brain teaching dapat disusun ulang, dicampur, disesuaikan dengan masingmasing guru. Langkah-langkah kegiatan di atas, menggunakan perintah-perintah dan respon sederhana yaitu class, yes, ajarkan, bergantian, tirukan, oke. Hal ini sesuai dengan pendapat Mukrimah (2014) bahwa metode whole brain teaching adalah metode pembelajaran yang penerapannya menggunakan perintah-perintah dan respon-respon sederhana. Langkahlangkah pembelajaran tersebut melibatkan pendengaran, penglihatan, berbicara atau menyampaikan cerita yang telah di dengar, aktivitas gerakan sederhana, serta perasaan anak yang juga turut dikembangkan ketika mendapatkan skor. Hal ini selaras dengan pendapat Biffle (Kusumayati \& Sumardiono, 2018) bahwa dalam penerapan metode whole brain teaching melibatkan pendengaran, penglihatan, berbicara, aktivitas, serta perasaan anak.

Temuan lain yang di dapat oleh peneliti dalam penelitian ini yaitu metode whole brain teaching dapat meningkatkan motivasi anak dalam mengikuti pembelajaran. Hal ini terlihat ketika mengikuti kegiatan ini anak-anak terlihat antusias dan bersemangat. Pembelajaran yang dikemas dalam bentuk permainan membuat anak-anak merasa senang, tertantang, dan berbeda dari biasanya. Keadaan ini selaras dengan ungkapan Novidayanti (2018) bahwa kelebihan dari metode whole brain teaching adalah menumbuhkan konsentrasi serta partisipasi anak dalam kegiatan pembelajaran, mengesankan sehingga materi mudah diingat oleh anak, meningkatkan keaktifan 
anak dalam mengikuti kegiatan pembelajaran, dan tidak hanya berpusat pada guru sehingga dapat meningkatkan motivasi dan kemampuan berkomunikasi. Adanya aktivitas gerakan dalam langkah penerapan metode whole brain teaching dapat membantu anak berkonsentrasi. Hal ini dikarenakan gerakan-gerakan dapat memberikan rangsangan pada otak kiri dan kanan sehingga dapat meningkatkan konsentrasi. Selaras dengan pendapat Nunung (Yanti et al., 2018) yang menyatakan bahwa gerakan sederhana dapat merangsang integritas kerja otak kiri dan kanan untuk menghasilkan koordinasi fungsi otak yang harmonis, sehingga meningkatkan kemampuan koordinasi tubuh, konsentrasi, memori, pemecahan masalah, serta kreativitas.

Selain itu, metode whole brain teaching ini dapat meningkatkan kepercayaan diri anak. Semula terdapat beberapa anak yang kurang percaya diri, malu-malu dalam mengikuti kegiatan, dan tidak mau ikut berbicara atau bernyanyi dengan anak-anak yang lainnya. Tetapi setelah metode ini diterapkan anak tersebut mulai menunjukkan adanya peningkatan rasa kepercayaan diri. Ketika mengikuti kegiatan dengan penerapan metode whole brain teaching, si anak dapat menyampaikan apa yang disimak kepada temannya, dan dapat menunjukkan ekspresi ketika mendapatkan skor. Hal ini sesuai dengan pendapat Cannon (Preslee \& Prakasha, 2017) bahwa dalam langkah teach-ok memberikan kesempatan anak untuk mendapatkan kepercayaan diri dan meningkatkan keterlibatan anak.

\section{SIMPULAN}

Merujuk pada hasil penelitian, data yang di dapat setelah adanya tindakan dengan penerapan metode whole brain teaching menunjukkan adanya peningkatan. Persentase hasil penelitian siklus I diperoleh 55,9\% atau sama dengan 19 anak yang memperoleh nilai tuntas. Persentase ketuntasan pada siklus II diperoleh $82,3 \%$ atau sama dengan 28 anak. Pada indikator menceritakan kembali informasi yang di dengar dengan urutan yang benar mengalami peningkatan sebesar 20,5\%. Indikator melaksanakan aturan dalam kegiatan meningkat sebesar 20,5\%. Peningkatan terjadi sebesar 26,4\% pada indikator memusatkan perhatian dalam mengikuti kegiatan.

Berdasarkan hasil tersebut, dapat di tarik kesimpulan bahwa penerapan metode whole brain teaching dapat meningkatkan kemampuan menyimak anak usia 5-6 tahun di TK Pertiwi Lebak Wonogiri pada Tahun Ajaran 2019/2020. Metode whole brain teaching ini dapat 
meningkatkan kemampuan menyimak dikarenakan :

1. Pada langkah - langkah penerapan metode ini, ada 4 langkah yang dapat menstimulasi anak untuk menyimak dan mengingat informasi berupa cerita pendek (langkah gestures, mirror, switch-ok, teach-ok).

2. Aturan kegiatan yang di kemas menjadi aba-aba sederhana dan bahasa yang digunakan mudah dipahami anak, memudahkan anak untuk menyimak aturan tersebut.

3. Adanya aktivitas gerakan dalam langkah-langkah penerapan metode whole brain teaching dapat membantu anak untuk berkonsentrasi.

\section{DAFTAR PUSTAKA}

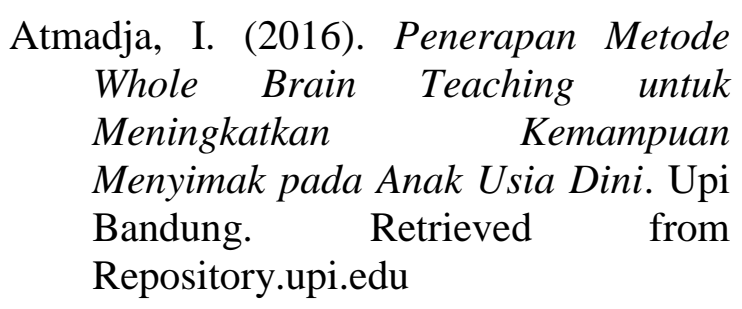

Aulina, C. N. (2018). Penerapan Metode Whole Brain Teaching dalam Meningkatkan Motivasi Belajar Anak Usia Dini. Jurnal Obsesi: Jurnal Pendidikan Anak Usia Dini 2.
Badiah, M. (2017). Mengembangkan Kemampuan Menyimak Melalui Metode Bercerita dengan Menggunakan Media Boneka Tangan pada Anak Kelompok A TK Kusuma Mulia Sidomulya I Kecamatan Puncu Kabupaten Kediri Tahun Pelajaran 2016/2017. Jurnal Simki-Pedagogia, $01(11)$.

Bourdeaud, H., Aesaert, K., Keer, H. Van, \& Braak, J. Van. (2018). Identifying student and classroom characteristics related to primary school students' listening skills: A systematic review. Educational Research Review. https://doi.org/10.1016/j.edurev.2018. 09.005

Daeng, K., Amir, J., \& Hamsa, A. (2010). Pembelajaran keterampilan menyimak. Makassar: Badan Penerbit Universitas Negeri Makassar.

Dhieni, N., \& Dkk. (2008). Metode pengembangan bahasa. Jakarta: Universitas Terbuka.

Gulec, S., \& Durmus, N. (2015). A Study Aiming To Develop Listening Skills Of Elementary Second Grade Students. Procedia - Social and Behavioral Sciences, 191, 103-109. https://doi.org/10.1016/j.sbspro.2015. 04.487

Hartati, S., \& Novrika, G. (2018). Using Educational Video to Promoting Listening Skill Children of 5-6 Years Old. Early Childhood Education Journal of Indonesian, 1(1).

Kemdikbud. (2014a). Peraturan menteri pendidikan dan kebudayaan Republik Indonesia Nomor 137 Tahun 2014. Jakarta: Departemen Pendidikan dan Kebudayaan.

Kemdikbud. (2014b). Peraturan menteri pendidikan dan kebudayaan Republik Indonesia Nomor 146 Tahun 2014. 
Jakarta: Departemen Pendidikan dan Kebudayaan.

Kepinska, O., Rover, M. De, Caspers, J., \& Schiller, N. O. (2016). Whole-brain functional connectivity during acquisition of novel grammar: Distinct functional networks depend on language learning abilities. Behavioural Brain Research. https://doi.org/10.1016/j.bbr.2016.12. 015

Kusumayati, L., \& Sumardiono. (2018). Penggunaan Metode Whole Brain Teaching pada Proses Pembelajaran di Taman Kanak-Kanak. Jurnal Adiwidya, 2.

Mukrimah, S. (2014). 53 Metode belajar dan pembelajaran. Bandung: Bumi Siliwangi.

Novidayanti, R. (2018). Pengembangan Perangkat Pembelajaran Matematika Berbasis Whole Brain Teaching pada Siswa SMP Swasta Alhikmah Meda T.P 2017/2018. Universitas Muhammadiyah Sumatra Utara Medan.

Nursulistyo, E. (2014). Kajian Metode Power Teaching sebagai Alternatif Metode Pembelajaran Sain di Kelas. JRKPF UAD, 1(1).

Preslee, M., \& Prakasha, D. K. (2017). Whole Brain Teaching, 22(6), 76-83. https://doi.org/10.9790/08372206027683

Priyanto, A. (2014). Pengembangan Kreativitas pada Anak Usia Dini melalui Aktivitas Bermain. Jurnal Ilmiah Guru “COPE” No. 02/Tahun XVIII/November 2014.

Puspitasari, R. (2019). Pengaruh Metode Pembelajaran Whole Brain Teaching terhadap Kemampuan Pemecahan Masalah Matematis ditinjau dari Multiple Intelligences Peserta didik. Uin Lampung.

Sugiyono. (2015). Metode penelitian pendidikan (pendekatan kuantitatif, kualitatif, dan $R \& D)$. Bandung: $\mathrm{CV}$ Alfabeta.

Tarigan, H. . (2008). Menyimak sebagai suatu keterampilan berbahasa. Bandung: Angkasa.

Upton, P. (2012). Psikologi perkembangan. (N. F. Widuri, Ed.). Jakarta: Erlangga.

Yanti, N., Bahri, S., \& Fajriani. (2018). Penggunaan Senam Otak dalam Meningkatkan Konsentrasi Belajar Siswa SD Negeri Ateuk Aceh Besar. Suloh Jurnal Bimbingan Konseling Universitas Syiah Kuala, 3(1), 28-34. Retrieved from http://jurnal.unsyiah.ac.id/suloh 